University of Nebraska - Lincoln

DigitalCommons@University of Nebraska - Lincoln

Faculty Publications from the Harold W. Manter Laboratory of Parasitology

2010

Discovery of New Ohbayashinema spp. (Nematoda:

Heligmosomoidea) in Ochotona princeps and Ochotona cansus

(Lagomorpha: Ochotonidae) from Western North America and

Central Asia, with Considerations of Historical Biogeography

\author{
M.-C. Durrette-Desset \\ Muséum national d'Histoire naturelle, Paris, France \\ Kurt E. Galbreath \\ Western Washington University, Kurt.Galbreath@wwu.edu \\ Eric P. Hoberg \\ United States Department of Agriculture, ehoberg@ggpl.arsusda.gov
}

Follow this and additional works at: https://digitalcommons.unl.edu/parasitologyfacpubs

Part of the Parasitology Commons

Durrette-Desset, M.-C.; Galbreath, Kurt E.; and Hoberg, Eric P., "Discovery of New Ohbayashinema spp. (Nematoda: Heligmosomoidea) in Ochotona princeps and Ochotona cansus (Lagomorpha: Ochotonidae) from Western North America and Central Asia, with Considerations of Historical Biogeography" (2010). Faculty Publications from the Harold W. Manter Laboratory of Parasitology. 638.

https://digitalcommons.unl.edu/parasitologyfacpubs/638

This Article is brought to you for free and open access by the Parasitology, Harold W. Manter Laboratory of at DigitalCommons@University of Nebraska - Lincoln. It has been accepted for inclusion in Faculty Publications from the Harold W. Manter Laboratory of Parasitology by an authorized administrator of DigitalCommons@University of Nebraska - Lincoln. 


\title{
DISCOVERY OF NEW OHBAYASHINEMA SPP. (NEMATODA: HELIGMOSOMOIDEA) IN OCHOTONA PRINCEPS AND OCHOTONA CANSUS (LAGOMORPHA: OCHOTONIDAE) FROM WESTERN NORTH AMERICA AND CENTRAL ASIA, WITH CONSIDERATIONS OF HISTORICAL BIOGEOGRAPHY
}

\author{
M.-C. Durette-Desset, K. E. Galbreath ${ }^{\star} \dagger$, and E. P. Hoberg $\ddagger \S$ \\ Département de Systématique et Evolution, Muséum national d'Histoire naturelle, UMR 7138 associée au CNRS, CP 52, 61 rue Buffon, 75231 Paris \\ cedex, 05, France. e-mail: eric.hoberg@ars.usda.gov
}

\begin{abstract}
Three new species of Ohbayashinema (Nematoda, Heligmosomoidea) are described from localities in western North America and central Asia. Two of these species, Ohbayashinema nearctica $\mathrm{n}$. sp. and Ohbayashinema aspeira n. sp., are parasitic in American pika, Ochotona princeps. Ohbayashinema nearctica is differentiated from the 5 known species of the genus parasitic in Ochotonidae from the Old World by very long spicules and an oblique axis of orientation for the ridges composing the synlophe. Ohbayashinema aspeira, described only from females, is similar to Oh. nearctica based on the number of cuticular ridges at the midbody. It is mainly differentiated by an uncoiled anterior extremity and by near equal dimensions of the vestibule and the uterus. The third species, Ohbayashinema patriciae n. sp., is parasitic in Gansu pika, Ochotona cansus, from China. It is similar to Ohbayashinema erbaevae parasitic in Ochotona dauurica from Buriatia and Ohbayashinema ochotoni in Ochotona macrotis from Nepal, based on the length of the spicules and the ratio of spicule length to body length. It differs from the former species by possessing a smaller number of cuticular ridges and in the comparative length of the vestibule and infundibulum. Related to Oh. ochotoni by an identical number of cuticular ridges at the mid-body, it differs from this species in having smaller ridges in the dorsal rather than ventral field and in the dimensions of the dorsal ray where rays 9 are less than rays 10. Species of Ohbayashinema appear to be host-specific among the Ochotonidae but had not been previously reported in pikas from the Nearctic. Although much remains to be demonstrated about the diversity for helminths in pikas, it is apparent that factors associated with the assembly and structure of parasite faunas have been complex, involving episodic processes for geographic and host colonization along with coevolutionary mechanisms. Understanding the historical factors, particularly climate-driven fluctuations in geographic range, that have structured these faunas suggests that the current regime for global warming and habitat modification has considerable implications for the continuity of already localized assemblages of hosts and parasites.
\end{abstract}

Ohbayashinema Durette-Desset, 1974, was established for heligmosomid nematodes characteristic of pikas (Lagomorpha: Ochotonidae). Currently 4 (or 5) species are known in the genus, including Ohbayashinema ochotoni Durette-Desset, 1974 (type) in Ochotona macrotis (Günther, 1875) from Nepal, Ohbayashinema abei Fukomoto, Kamyia and Ohbayashi, 1986, in Ochotona hyperborea (Pallas, 1811) from Hokkaido, Japan, Ohbayashinema dubinini (Gvozdev, 1966) in Ochotona alpina (Pallas, 1773) from the Altai region of Russia, and Ohbayashinema erbaevae DuretteDesset, Ganzorig, Audebert and Kamiya, 2000 in Ochotona dauurica (Pallas, 1776) from Buriatia (Durette-Desset, 1974a; Durette-Desset et al., 2000). An additional species may be represented by Heligmosomum mongolicum (Danzan, 1976) in Ochotona dauurica from Mongolia, although confirmation of its status as an independent species or as a synonym of Oh. erbaevae is required (Durette-Desset et al., 2000). Based on these host associations and geographic records, it was considered that the distribution of Ohbayashinema might be limited to species of Ochotona from the eastern Palearctic. Such a contention was supported by parasitological survey, particularly of the American pika (Ochotona princeps (Richardson, 1828)) across the intermountain regions of western North America where species of Ohbayashinema had not been represented in an otherwise diverse

Received 17 November 2009; revised 15 January 2010; accepted 21 January 2010

* Department of Ecology and Evolutionary Biology, Cornell University, Ithaca, New York 14853.

$\dagger$ Current address: Department of Biology, Western Washington University, Bellingham, Washington 98225.

*United States National Parasite Collection, Parasitic Disease Laboratory, Agricultural Research Service, USDA, BARC East No. 1180 , 10300 Baltimore Avenue, Beltsville, Maryland 20705.

$\S$ To whom correspondence should be addressed.

DOI: 10.1645/GE-2397.1 helminth fauna (e.g., Olsen, 1948; Barrett and Worley, 1970; Seesee, 1973; Grundmann and Lombardi, 1976; Hobbs, 1980). Notably, this fauna included Murielus harpespiculus Dikmans, 1939, and Graphidiella ochotonae Olsen, 1948, representing 2 other genera of Trichostrongylina that have Holarctic distributions in pikas (Gvozdev, 1962; Gvozdev et al., 1970; Hoberg, 2005); interestingly, trichostrongyline nematodes are unknown in collared pika (Ochotona collaris (Nelson, 1893)) from Alaska and the Northwest Territories and the Yukon Territory in Canada (Hoberg, 2005; Galbreath, 2009).

Recent integrated and large-scale biodiversity surveys for mammalian hosts and their macroparasites have included pikas in both the Nearctic (Cook et al., 2005; Galbreath, 2009) and Palearctic (Tinnin et al., 2008). Extensive field collections across the geographic range for Oc. princeps during 2004-2005 revealed specimens of Ohbayashinema in 2 American pikas at a single isolated locality in Washington State (among 394 pikas from 37 host populations sampled from Alberta and British Columbia in the north to California and New Mexico in the south) (Galbreath, 2009). Concurrently, during a related study (E. P. Hoberg and K. E. Galbreath, unpubl. obs.), a re-examination of type specimens for M. harpespiculus in Oc. princeps from Wyoming, held in the U.S. National Parasite Collection (USDA, Agricultural Research Service, Beltsville, Maryland) under USNPC 30461, revealed the presence of additional specimens attributable to Ohbayashinema. These miniscule nematodes had been collected in a multi-species infection from the type host of $M$. harpesiculus by O. J. Murie in 1930, but had apparently been overlooked by Dikmans (1939). Later, collections of Gansu pikas (Ochotona cansus Lyon, 1907), from central China in 2005, resulted in the recovery of other specimens of Ohbayashinema, and the first from this host species (K. E. Galbreath, unpubl. obs.). Parasitological material in $O c$. cansus was obtained from an international research team funded by 
the National Institutes of Health (Ecology of Infectious Diseases) conducting small mammal surveys for species of Echinococcus Rudolphi, 1801, throughout China (e.g., Giraudoux et al., 2006). This highlights the potential for discovering new diversity by coordinating efforts between large-scale monitoring programs.

Based on these survey collections, and material held in the USNPC, in the current study we describe 3 previously unknown species of Ohbayashinema from western North America and central Asia. Further, we explore some aspects of historical biogeography for this assemblage of nematodes among species of Ochotona across the Holarctic.

\section{MATERIALS AND METHODS}

\section{Specimens examined}

All specimens representing Ohbayashinema in American and Gansu pikas were examined and included in the descriptions except for some vouchers that had been sub-sampled for molecular-based analyses. These included as follows: (1) American pikas, KG 338 (2 oro and 2 oᄋ nematodes) and KG 340 (2 o'o and 2 oo nematodes and fragments) from near Trout Lake, Washington; (2) American pika, near Jackson, Wyoming (2 @ᄋ nematodes); (3) Gansu pika, KG 559 (4 ơం', 4 ㅇ nematodes), in 1 of 2 hosts, from Sichuan, China. Complete data for collection are outlined in the taxonomic summaries for respective species. Nematode specimens are now held in the U.S. National Parasite Collection.

\section{Microscopy}

Specimens were initially examined as temporary whole mounts cleared in phenol-alcohol ( 80 parts melted phenol crystals and 20 parts absolute ethanol) under differential interference contrast microscopy. The synlophe was studied following the method of Durette-Desset (1985). The nomenclature for the number of cuticular ridges among species of Ohbayashinema follows Durette-Desset et al. (2000). The nomenclature used for the study of the caudal bursa follows Durette-Desset and Chabaud (1981). The parasite classification used for the family group follows Durette-Desset and Chabaud (1993). Measurements are given in micrometers except where stated otherwise.

\section{Host nomenclature and specimens}

Taxonomy for species of Ochotona follows Hoffmann and Smith (2005) and with reference to details for geographic range as outlined by Smith et al. (1990).

Host symbiotype and vouchers for $O c$. princeps are deposited in the mammal collections of the Cornell University Museum of Vertebrates, Ithaca, New York

\section{RESULTS}

Specimens representing 3 undescribed species of Ohbayashinema were found as parasites in pikas. Of these, 2 species occur in the small intestine of Oc. princeps from geographically discrete host populations at separate sites in western North America; in all hosts, Ohbayashinema co-occurred with $M$. harpespiculus in the small intestine. A third species was found in the small intestine of 1 of 2 Oc. cansus from western Sichuan, China; these parasites occurred in a mixed infection with Murielus tjanschaniensis (Gvozdev, 1962).

\section{DESCRIPTIONS}

\section{Ohbayashinema nearctica $\mathrm{n}$. sp.}

$$
\text { (Figs. 1-10) }
$$

General: Heligmosomidae, small nematodes, strongly coiled sinistrally along ventral side with 7 spirals in males and 17 to 21 in females. Deirids not observed. Excretory glands well developed (Fig. 1).
Synlophe: (Studied in 1 male and 1 female paratype.) In both sexes, cuticle bearing longitudinal, uninterrupted ridges without struts. Ridges originate posterior to cephalic vesicle, terminating at about 100 anterior to caudal bursa in male; 150 anterior to caudal extremity in female. Number of ridges at mid-body, 16 ( 9 dorsal/7 ventral) in female (Fig. 4), 15 (9 dorsal/6 ventral) in male (Fig. 5). Same number in male at level of proximal end of spicules (Fig. 6). Presence of 1 ridge in front of each lateral field. Ventral ridges best developed with decreasing latero-median gradient of size. On dorsal side, small ridges of similar size. Axis of orientation directed from right to left, inclined at $65^{\circ}$ in female, $73^{\circ}$ to sagittal axis in male (Figs. 4, 5).

Holotype male and paratype (in parentheses): Length 12.2 (9.4) mm, 100 (100) wide at mid-body; cephalic vesicle 100 (95) long and 38 (35) wide; nerve ring and excretory pore situated $280(-)$ and $540(420)$ from cephalic extremity, respectively. Esophagus 680 (550) long. Caudal bursa slightly asymmetrical with right lobe more developed (Fig. 7). Prebursal papillae developed. Caudal bursa pattern of type 2-3 for both lobes. Ray 3 largest. Rays 4 and 5 divergent at two-thirds of length. Rays 6 diverging from lateral trident before separation of rays 4 and 5. Rays 8 of similar length, diverging on common trunk of rays 2 to 6 (Fig. 9). Dorsal ray reduced, observed only in paratype (Fig. 8); divided at extremity into 2 branches, external (rays 9) and internal (rays 10) apparently merged. Additional material would be necessary to check this point. Genital cone observed only in ventral view, 80 long and 20 wide at the most, bearing 2 long papillae 7 on dorsal lip, papilla zero not observed (Fig. 8). Gubernaculum absent; spicules subequal, 3.8 (3.75) mm long, 3.1\% (3.9) of body length, ending in sharp tip 50 long (Fig. 10). Spicules divided into 2 closely attached parts of similar size except at both extremities.

Allotype female and paratype (in parentheses): Length 13.3 (15.3) $\mathrm{mm}$ and $100(130)$ wide at mid-body. Cephalic vesicle 100 (120) long and 45 (50) wide. Nerve ring and excretory pore situated $260(-)$ and $480(570)$ from cephalic extremity, respectively. Esophagus 700 (820) long (Fig. 1). Monodelphic with atrophied, non-functional posterior genital branch Presence of muscular "masse" posterior to vulva 50 (70) long and $30(30)$ wide (Fig. 2). Vulva situated 280 (230) from caudal extremity. Vagina vera 70 (50) long, vestibule $1.45(2.5) \mathrm{mm}$ long, divided into 3 distinct parts with a muscular short proximal part, a thin median part, and long dista part without swelling (Fig. 3). Sphincter 55 (75) long and 62 (75) wide, infundibulum 190 (-) long. Atrophied genital branch: 160 (120) (Fig. 2). Uterus 3.5 (3.3) mm long, 26.1\% (21.5) of body length with $97(>150)$ eggs at morula stage. Tail 90 (60) long with caudal spine 12 (10) long (Fig. 2).

Measurements (range and average) of 2 females representing additional paratype material (broken specimen in parentheses): $16.1 \mathrm{~mm}(1.5 \mathrm{~mm}$ anterior part, $2.8 \mathrm{~mm}$ posterior part) long and 150 wide at mid-body (100 anterior part, 110 posterior part). Cephalic vesicle 110 (95) long and 50 (35) wide. Nerve ring and excretory pore situated (270) and 470 (450) from cephalic extremity, respectively. Esophagus 710 (720) long. Vulva situated 280 (330) from caudal extremity. Vagina vera 75 (-) long, ovejector, 2.0 (1.9) $\mathrm{mm}$ long with vestibule $1.7(-) \mathrm{mm}$ long, sphincter $60(-)$ long and 80 (-) wide, infundibulum $130(-)$ long. Atrophied genital branch 140 (140) long (Fig. 3). Uterus $2.7(-)$ mm long, 16.8\% (-) of body length. $117(-)$ eggs; 70-80 (69-78) long and 40-52 (37-45) wide. Tail 80 (80) long with spine 10 (10) long (Fig. 3).

\section{Taxonomic summary}

Type host: Ochotona princeps (Richardson, 1828).

Type locality: In type host (female, KG 340) from rock talus slopes located $19 \mathrm{~km}$ west of Trout Lake, Washington State; ca. $46^{\circ} 3^{\prime} 10^{\prime \prime} \mathrm{N}$, $121^{\circ} 45^{\prime} 31^{\prime \prime} \mathrm{W}$. Also in additional host (female, KG 338) at adjacent site in talus slope at ca. $46^{\circ} 3^{\prime} 9^{\prime \prime} \mathrm{N}, 121^{\circ} 45^{\prime} 32^{\prime \prime} \mathrm{W}$. Collected by K.E.G. on 15 August 2004. Other localities currently unknown.

Specimens: Holotype male USNPC No. 100,991; allotype female USNPC 102,683; paratypes, single male and female, USNPC 102,684; and voucher specimens, USNPC 102,685, including 2 males and 1 female represented by cephalic and caudal extremities, with midbody sampled for DNA sequence analyses, all from type host (KG 340) and locality. Additional paratype specimens, USNPC 100,992, include 2 males, 1 complete female, and 1 broken female from second host specimen (KG 338) adjacent to type locality; voucher specimens USNPC 102,686 include cephalic and caudal ends of 2 females sampled for sequencing.

Site in host: Small intestine. 

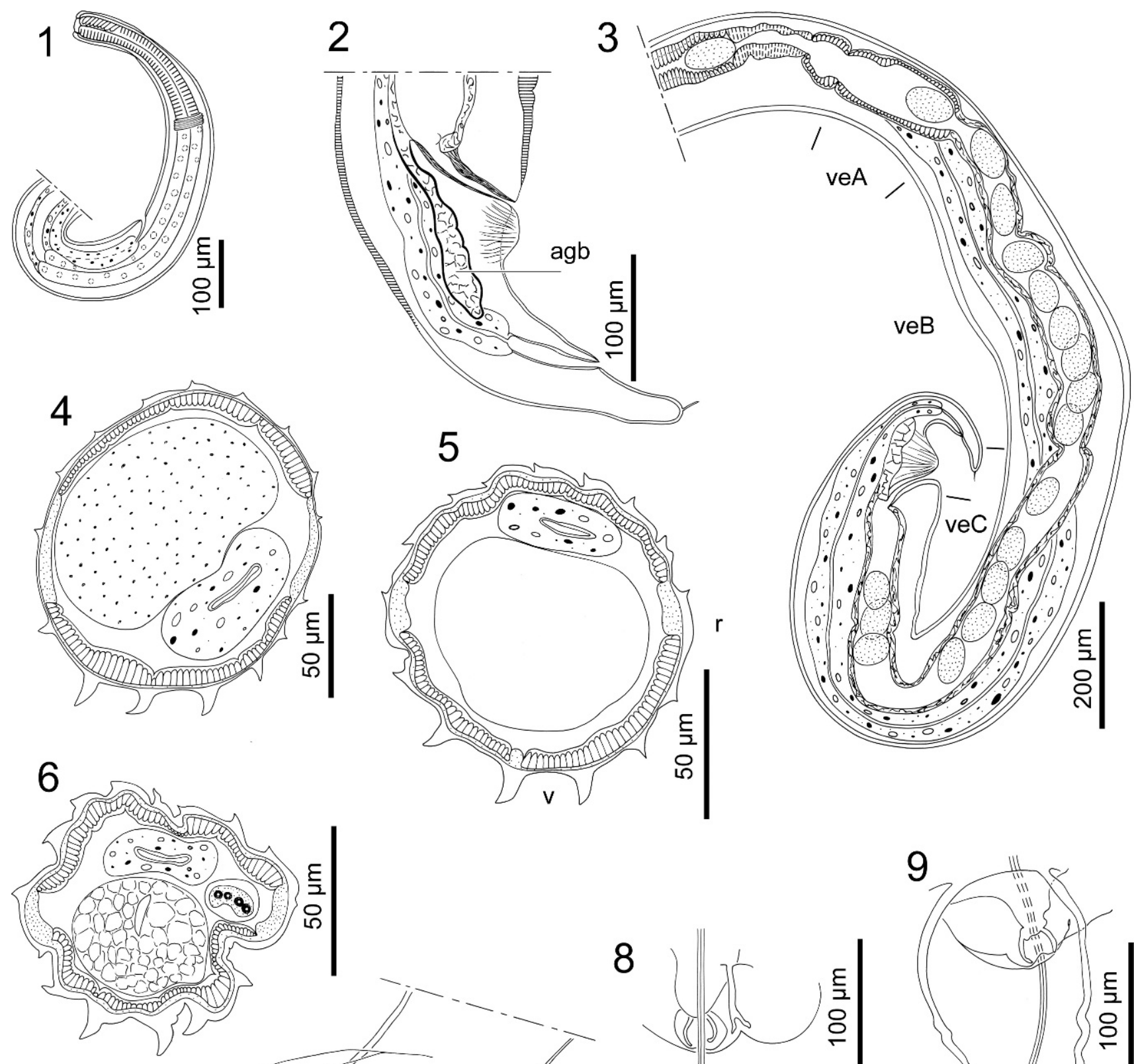
Symbiotype: Ochotona princeps, female (KG 340), Cornell University Museum of Vertebrates, CUMV No. 20309 (skull, skeleton, and frozen tissues); additional host specimen, female (KG 338), CUMV No. 20307.

Etymology: The specific name "nearctica" denotes the first North American occurrence for any species of Ohbayashinema.

\section{Remarks}

The genus Ohbayashinema, created by Durette-Desset (1974a), has been recognized until now exclusively for species occurring as parasites in Ochotonidae from the Old World. The caudal bursa is similar to species of Citellinema Hall, 1916, parasitic in Nearctic Sciuromorpha, as well as Heligmosomoides Hall, 1916, and Heligmosomum Railliet and Henry, 1909, both parasitic mainly in Holarctic Arvicolinae. Ohbayashinema is easily distinguished from the other genera by the structure of the genital apparatus, which is semi-monodelphic with an atrophied, non-functional posterior genital branch. In contrast, the female genital system is didelphic in Citellinema and monodelphic in Heligmosomum-Heligmosomoides. In addition, in Ohbayashinema the number of the cuticular ridges is less than 15 with a frontal or sub-frontal axis of orientation, the presence of a medio-lateral gradient of ridges at least on the ventral side of the body, and the absence of ridges in front of the lateral fields. Ohbayashinema nearctica $\mathrm{n}$. sp. is referred to this genus based on the structure of the caudal bursa, a semi-monodelphic genital system and a latero-median gradient in size for ventral ridges. Specimens of Oh. nearctica are clearly differentiated from the 4 currently described species in pikas from the eastern Palearctic (Oh. dubinini, Oh. ochotoni, Oh. abei, and Oh. erbaevae) by the length of the spicules (3.1-3.8 mm versus $500 \mu \mathrm{m}$ to $1.4 \mathrm{~mm}$ ). In addition the presence of 1 ridge in front of each lateral field results in an oblique axis of orientation for Oh. nearctica, whereas it is sub-frontal in all other currently known species. We consider these specimens in $O c$. princeps from Washington State to represent a new species, and the first of the genus to be recognized in the Western Hemisphere.

\section{Ohbayashinema aspeira $\mathrm{n} . \mathrm{sp}$.}

(Figs. 11-16)

General description: Heligmosomidae, small nematodes, strongly coiled sinistrally along ventral side with 10-12 spirals except about the anterior part of the body (about an eighth of body). Deirids not observed. Excretory glands well developed (Fig. 11).

Synlophe (studied in broken paratype female): Cuticle bearing longitudinal, uninterrupted ridges without struts. Ridges originate posterior to cephalic vesicle, terminating at about 200 anterior to vulva in female. Number of ridges, 16 ( 9 dorsal/7 ventral) at level of esophago-intestinal junction (Fig. 15); 15 (9 dorsal/6ventral) at mid-body (Fig. 16). Absence of ridges in front of each lateral field. Ventral ridges best developed with a decreasing latero-median gradient of size. On dorsal side, small ridges of similar size. Dorsal ridges more developed in anterior part of body than at mid-body. Axis of orientation sub-frontal (Fig. 16).

Holotype female and paratype (in parentheses): 16.3 (16.4) $\mathrm{mm}$ long, 150 (150) wide at mid-body; cephalic vesicle 120 (95) long, 52 (50) wide. Nerve ring and excretory pore situated 250 (190) and 410 (340) from cephalic extremity, respectively. Esophagus 760 (700) long (Fig. 11). Monodelphic with atrophied, non-functional posterior genital branch. Vulva situated 360 (470) from caudal extremity. Vagina vera 90 (85) long, Ovejector 3. 3 (2.85) $\mathrm{mm}$ long with vestibule $3.1(2.55) \mathrm{mm}$ long, divided into 2 distinct parts with short muscular proximal part 240 (230) long (Fig. 12), and another narrower part made up of median and distal parts not clearly differentiated; sphincter 75 (70) long and 60 (60) wide, infundibulum 180 (140) long (Fig. 13). Atrophied genital branch, 160 (120). (Figs. 13, 14). Uterus $3.6(2.5) \mathrm{mm}$ long, 22\% (15.2) of body length with $100(>140)$ eggs at morula stage. Muscular mass posterior to vulva not observed (this is perhaps due to the poor state of the material). Tail 90 (60) long with caudal spine 10 long (Figs. 13, 14).

Male: Currently unknown.

\section{Taxonomic summary}

Host: Ochotona princeps ventorum Howell, 1919.

Locality: In type host from Teton Range, near Jackson, Wyoming; ca. $43^{\circ} 45^{\prime} \mathrm{N}, 110^{\circ} 50^{\prime} \mathrm{W}$. Collected by Olaus J. Murie on 30 October 1930. Other localities currently unknown.
Specimens: Holotype female USNPC No. 100,989; paratype, single damaged female (level of nerve ring), USNPC 102,687. Occurred as coparasites with type specimens of M. harpespiculus Dikmans, 1939.

Site in host: Small intestine.

Etymology: From the Greek "a" privative alpha and "speira" spire, a reminder that the anterior part of the body is uncoiled.

\section{Remarks}

Although the material described above comprises only 2 females, it is unequivocally referred to Ohbayashinema based on the features of the synlophe, a very long vestibule, and an atrophied non-functional distal branch of the genital system. Morphologically, specimens are most similar to Oh. nearctica in having a similar number of cuticular ridges at the midbody (15 versus 16), whereas in the other Ohbayashinema, this number comprises between 12 and 14. Females described above are easily differentiated from Oh. nearctica by the following features: anterior extremity uncoiled, length of vestibule $17.3 \%$ of body length for a female of $16.1 \mathrm{~mm}$ long, and uterus same length as ovejector. In specimens of $\mathrm{Oh}$. nearctica, the anterior extremity is strongly coiled, the length of vestibule is $11.8 \%$ of body length for a female of $16.4 \mathrm{~mm}$ long, and the length of the uterus greatly exceeds that of the vestibule. We consider the specimens described above as a previously unrecognized species for which we propose Ohbayashinema aspeira $\mathrm{n}$. sp.

\section{Ohbayashinema patriciae n. sp.}

(Figs. 17-32)

General description: Heligmosomidae, small nematodes irregularly coiled sinistrally along ventral side; slightly in males, strongly in females. Cephalic vesicle obscure or cryptic. Deirids situated just posterior to excretory pore, seitiform, observed only in 2 males (Fig. 27). Excretory glands well developed (Fig. 26).

Synlophe (studied in various bits of paratype males and females): In both sexes cuticle bearing longitudinal, uninterrupted ridges without struts. Eight ridges originate posterior to cephalic vesicle on median sides (4 dorsal/4 ventral) (Fig. 19). Other ridges appear at different levels between cephalic vesicle and oesophago-intestinal junction in male and up to about one-fifth anterior part of body in female (Figs. 20-23) to reach stage 18 (9 dorsal/9 ventral) (Figs. 17, 24); number of ridges decreases regularly to reach 10 ( 5 dorsal $/ 5$ ventral) within anterior third. In male, ventral ridges terminate first, then dorsal ridges anterior to caudal bursa. In female, ridges terminate anterior to vulva, dorsal being barely visible. Number of ridges: 18 (9 dorsal, 9 ventral) in male (Fig. 17), 15 (8 dorsal, 7 ventral) in female (Fig. 23) at level of esophago-intestinal junction; 10 (5 dorsal, 5 ventral) at mid-body in both sexes (Figs. 18, 25). At mid-body, absence of ridge in front of each lateral field; ventral ridges best developed with decreasing latero-median gradient of size, small dorsal ridges of similar size; axis of orientation directed from right to left, inclined at $90^{\circ}$ to sagittal axis in both sexes (Figs. 18, 25). In anterior part of body in male, all ridges of similar size oriented perpendicular to body surface except 2 ridges in front of each lateral field with latero-dorsal ridges oriented to dorsal side and latero-ventral ridges to ventral side (Figs. 17, 24).

Holotype male and entire paratype (in parentheses): 8.6 (7.5) $\mathrm{mm}$ long, 110 (100) wide at mid-body, up to 120 (105) in posterior part of body. Cephalic vesicle 110 (85) long and 40 (30) wide. Nerve ring, excretory pore, and deirids situated 320 (225), 460 (390), and 460 (405) from cephalic extremity, respectively. Esophagus 950 (710) long (Fig. 26). Caudal bursa asymmetrical with right lobe more developed (Fig. 32). Prebursal papillae not observed. Caudal bursa pattern of type 2-3 for both lobes. Rays 3 largest. Rays 4 and 5 diverging at two-thirds of length. Rays 6 diverging from lateral trident before separation of rays 4 and 5 . Rays 8 of similar length, arising on common trunk of rays 2 to 6 (Fig. 30). Dorsal ray reduced and divided at extremity into 2 branches, external (rays 9) shorter than internal (rays 10) (Fig. 30). Genital cone observed only in ventral view, $40(-)$ long and $30(-)$ wide at base, bearing 2 long papillae 7 on dorsal lip, papilla zero not observed (Fig. 30). Gubernaculum absent; spicules subequal, $520(520) \mathrm{mm}$ long, 6\% (6.9) of body length, ending in sharp tip 23 (20) long (Fig. 31). Spicules divided into 2 closely attached parts of similar size except at both extremities.

Measurements of 2 anterior and 2 posterior parts of male paratypes: Anterior parts: $2.2,4.6 \mathrm{~mm}$ long. Cephalic vesicle -, 90 long and -, 50 wide. Nerve ring excretory pore situated 320,260 and 470, 460 from 

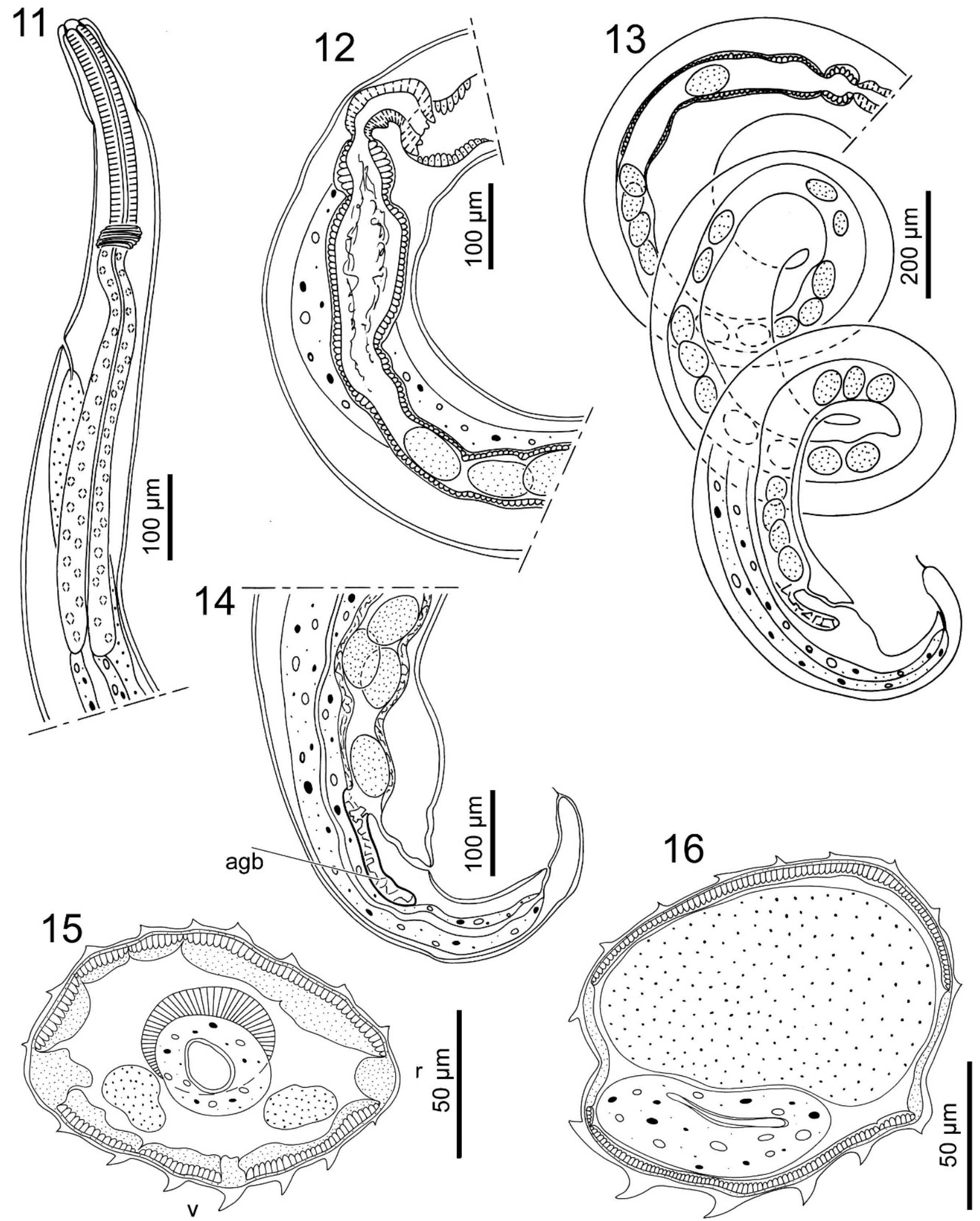

Figures 11-16. Ohbayashinema aspeira n. sp. in Ochotona princeps showing structure of female. (11) Anterior extremity, left lateral view. (12-14) Ovejector and tail. (12) Proximal part of the ovejector with infundibulum, sphincter, and muscular part of vestibule, right lateral view. (13) Caudal extremity showing sphincter, vestibule, atrophied genital branch, and tail, right lateral view. (14) Distal part of the vestibule, atrophied genital branch, and tail, right lateral view. $(\mathbf{1 5}, \mathbf{1 6})$ Synlophe as seen in transverse sections of body. (15) Level of the esophago-intestinal junction. (16) Mid-body. Specimens depicted are as follows: 11-13, holotype; 14-16, paratype. All sections are oriented as in Figure 15. Abbreviations: agb, atrophied genital branch; $v$, ventral side; $r$, right side. 

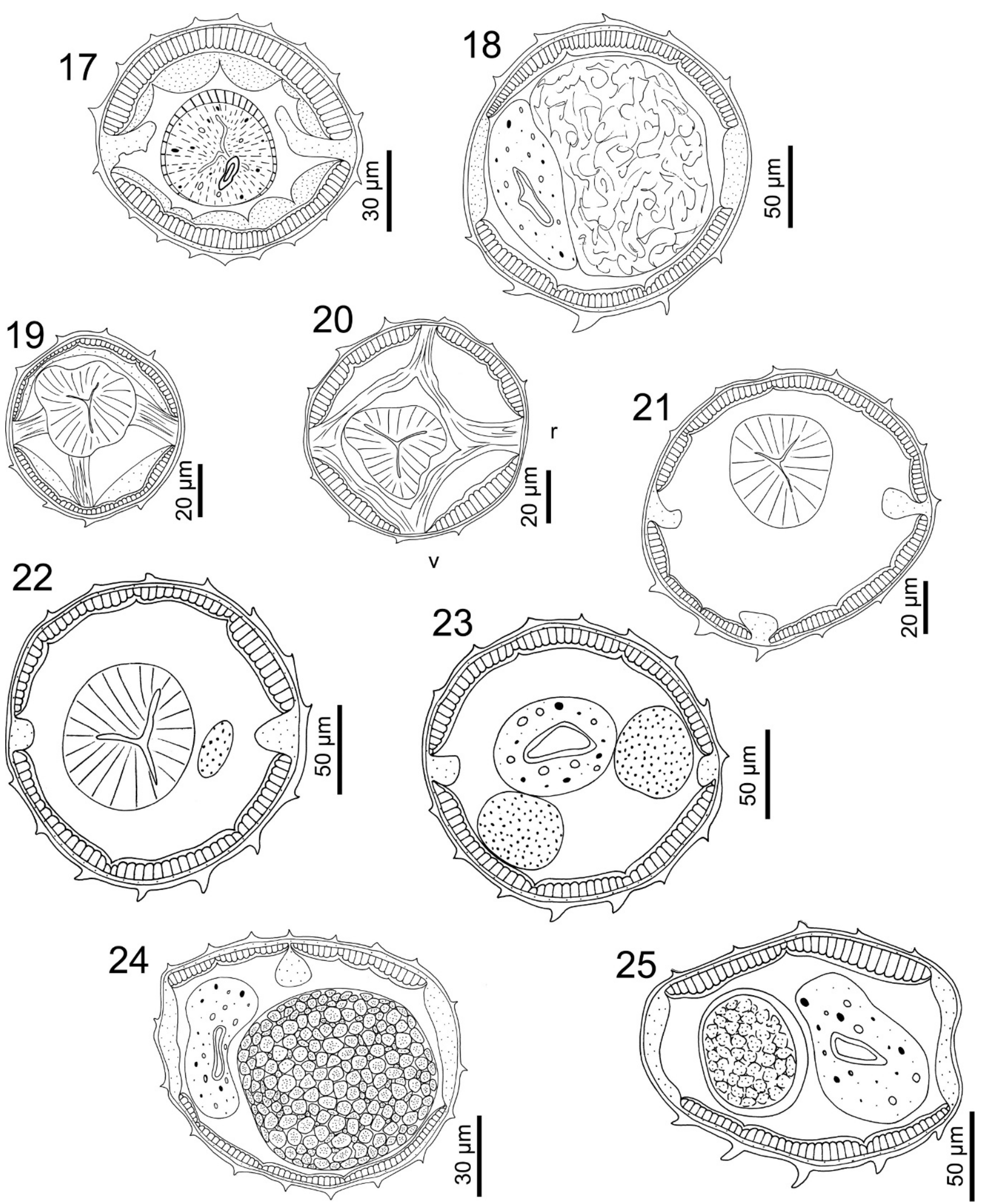

FIGURES 17-25. Ohbayashinema patriciae n. sp. in Ochotona cansus, showing structure of synlophe as seen in transverse sections from paratypes. (17, 18) Male. (17) Synlophe at oesophago-intestinal junction, stage 9/9. (18) Mid-body (3.5 mm from caudal bursa), stage 5/5. (19-25) Female. (19) Synlophe at $80 \mu \mathrm{m}$ posterior to cephalic vesicle, stage 4/4. (20) Level of nerve ring, stage 6/4. (21) Anterior to excretory pore, stage 7/5. (22) At 50 $\mu \mathrm{m}$ anterior to esophago-intestinal junction, stage 7/7. (23) At level of oesophago-intestinal junction, stage 8/7. (24) At $3.6 \mathrm{~mm}$ from cephalic extremity (about the fifth of body), stage 9/9. (25) Median part of body (distal part of ovary, about $5 \mathrm{~mm}$ from caudal extremity), stage 5/5. All sections are oriented as in 20. Abbreviations: $v$, ventral side; $r$, right side. 

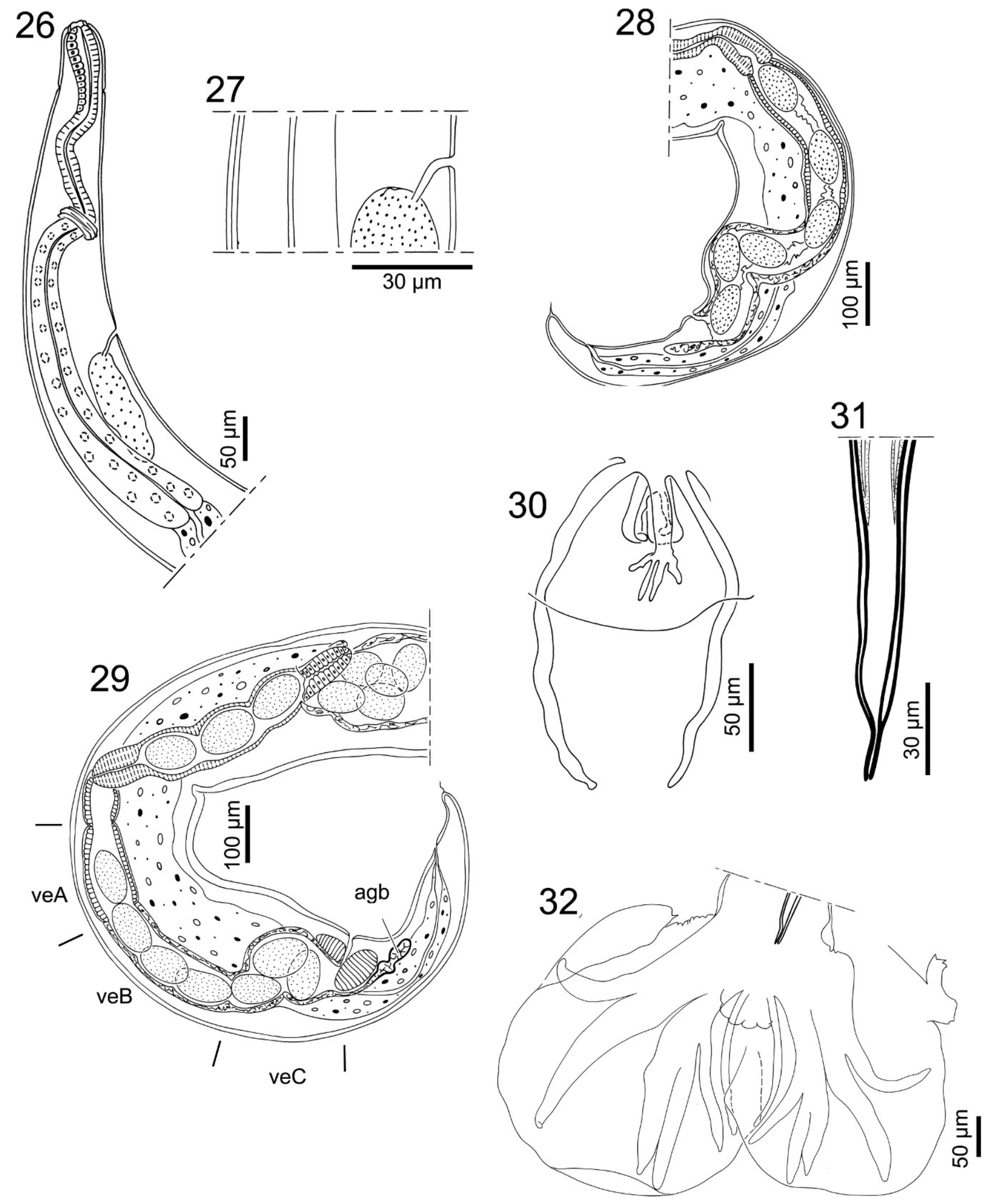

Figures 26-32. Ohbayashinema patriciae n. sp. in Ochotona cansus, showing structural characters in male and female specimens. (26, 27) Male, anterior extremity. (26) Right lateral view. (27) Detail of excretory pore and deirid, right lateral view. (28, 29) Female, posterior extremity. (28) Sphincter, vestibule, and tail, left lateral view. (29) Ovejector and tail, right lateral view. (30-32) Male, genital structures. (30) Dorsal ray, genital cone, and rays 8, dorsal view. (31) Spicule tips in situ, ventral view. (32) Caudal bursa, ventral view. The anterior part is torn. Specimens depicted are as follows: 26, 27, 29-32, paratypes; 28, allotype female. Abbreviations: d, deirid; agb, atrophied genital branch; veA, muscular proximal part of vestibule; veB, thin median part; veC, swollen distal part. 
cephalic extremity, respectively. Esophagus 710, 900 long. Posterior parts: 2.4, $3.5 \mathrm{~mm}$ long, 90 , 110 wide. Spicules 500, 520 long.

Allotype female: $17.0 \mathrm{~mm}$ long, 100 wide at mid-body, 200 at level of ovejector. Cephalic vesicle 90 long, 50 wide. Nerve ring, excretory pore situated 260, 380 from cephalic extremity, respectively. Esophagus 750 long. Monodelphic with atrophied, non-functional posterior genital branch. Vulva situated 340 from caudal extremity. Vagina vera 100 long, vestibule $490 \mathrm{~mm}$ long, divided into 3 distinct parts (Fig. 29) with muscular proximal part 200 long, rectilean median part 150 long, swollen distal part 140; sphincter 80 long, 60 wide, infundibulum length not determined. Atrophied posterior genital branch 90 (Fig. 28). Uterus about 3.2 long, $18.8 \%$ of body length with more than 80 eggs, 80 (78-82) long and 43 (40-50) wide at morula stage. Tail 100 long with caudal spine 15 long (Fig. 28).

Measurements of 3 anterior parts and 1 posterior part of female paratypes: Anterior part: 3.6, 6.0, $4.9 \mathrm{~mm}$ long. Cephalic vesicle -, 80, 90 long, -, 50, 60 wide. Nerve ring, excretory pore situated at 210, 150, 260 and 250, 200, 430 from cephalic extremity, respectively. Esophagus 520, 890, 950 long. Posterior part: $2.2 \mathrm{~mm}$ long. Vulva situated 420 from caudal extremity. Vagina vera 70 long, ovejector $1.12 \mathrm{~mm}$ long with vestibule $620 \mathrm{~mm}$ long (proximal part, 150, median part, 230, distal part, 240 long) sphincter 100 long, 70 wide, infundibulum 400 long (Fig. 29). Atrophied genital branch, 150 long (Fig. 29). Uterus $3.3 \mathrm{~mm}$ long with more than 150 eggs, 86.5 (8090) long, 58 (50-70) wide. Tail 100 long with spine 16 long (Fig. 29).

\section{Taxonomic summary}

Host: Ochotona cansus Lyon, 1907.

Locality: In type host from Maerkang, western Sichuan, China; ca. $31^{\circ} 43^{\prime} 3^{\prime \prime} \mathrm{N}, 102^{\circ} 17^{\prime} 19^{\prime \prime} \mathrm{E}$. Other localities currently unknown.

Specimens: Holotype male USNPC No. 100,990; alloptype female USNPC 102,688; paratype specimens USNPC 102,689 include males with 1 complete specimen, 2 anterior parts, 1 median part, and 2 posterior parts; and females with 3 anterior parts, 1 median part, and 2 posterior parts; vouchers include additional transverse sections under USNPC 102,690 .

Site in host: Small intestine.

Etymology: The species is dedicated to Patricia A. Pilitt, Associate Curator for the U.S. National Parasite Collection, in recognition of her significant contributions to parasite biodiversity collections and nematode systematics.

\section{Remarks}

These specimens are referred to Ohbayashinema based on the synlophe and structure of the semi-monodelphic genital apparatus in females. Specimens are most similar to those of Oh. erbaevae and Oh. ochotoni based on the length of the spicules $(500-520 \mu \mathrm{m}$ vs. 530 in Oh. erbaevae and $560 \mu \mathrm{m}$ in Oh. ochotoni) and the ratio of spicule length/body length (6.4-7.1\% vs. 5.9 and 6.4\%) (Durette-Desset, 1974a; Durette-Desset et al., 2000). Further, similarity to Oh. erbaevae is seen in the size and the gradient of the cuticular ridges, but the number at the mid-body is 14 in males, 12 in females of Oh. erbaevae versus 10 in both sexes for the specimens described above. In Oh. erbaevae, the vestibule is about twice as long as the infundibulum, but in the Chinese specimens it is only slightly longer. Specimens in Oc. cansus share with Oh. ochotoni the same number of cuticular ridges at the mid-body in both sexes ( 5 dorsal and 5 ventral); however, in the latter species the dorsal and the ventral ridges are of equivalent size, and there is a double medio-lateral decreasing gradient of size present on each side. Also, in the Chinese specimens, the dorsal ridges are smaller than the ventral ridges, and the gradient in size is present only on the ventral side. In addition, in the Chinese specimens, rays 9 are smaller than rays 10 , but in Oh. ochotoni these rays are equal in length. The variations concerning these rays have been described in Oh. erbaevae, but do not affect their relative length (Durette-Desset et al., 2000). We consider the specimens from China to be clearly differentiated from their congeners and to represent a previously undescribed species for which the name Ohbayashinema patriciae $\mathrm{n}$. $\mathrm{sp}$. is proposed.

In the Heligmosomoidea, the number of the cuticular ridges increases from the cephalic vesicle to the esophago-intestinal junction or sometimes a little further and then remains constant up to the end of the body. In $\mathrm{Oh}$. erbaevae and $\mathrm{Oh}$. patriciae, this number increases, then decreases before becoming constant. This feature is probably a characteristic of the genus
Ohbayashinema, but must be checked in the other species in which only the synlophe at mid-body has been described. The consequence is that if the section of the body is done at a level that is too anterior, the number of the cuticular ridges is not representative of the species.

\section{DISCUSSION}

\section{Ohbayashinema species in the New World}

Species representing Ohbayashinema are documented for the first time in the Western Hemisphere, establishing the Holarctic distribution for these heligmosomids as host-specific parasites among pikas (Durette-Desset et al., 2000). Pikas include 30 species, with 28 occurring in Eurasia, and only 2, Oc. princeps and Oc. collaris, represented in the Nearctic (Smith et al., 1990; Hoffmann and Smith, 2005). Overall for Ohbayashinema, we now recognize 5-6 species limited to particular species of pikas from the Palearctic, and 2 species that are likely restricted to $O c$. princeps from North America. Species of Ohbayashinema appear to be relatively rare and local parasites based on absence in extensive survey and inventory of $O c$. princeps across widespread localities in western North America (Olsen, 1948; Barrett and Worley, 1970; Seesee, 1973; Grundmann and Lombardi, 1976; Hobbs, 1980; Galbreath, 2009). Further, biodiversity survey in Alaska, Northwest Territories, and the Yukon Territory, now involving in excess of 200 specimens of Oc. collaris, has consistently failed to demonstrate the presence of this or any other trichostrongyline nematodes (Hobbs, 1980; Hoberg, 2005; Beringian Coevolution Project, unpubl. obs.). The absence of particular species-groups of Trichostrongylina in Oc. collaris, which are present in Oc. princeps, is apparently a recurring pattern across phylogentically disparate helminth taxa that infect pikas in North America (Galbreath, 2009).

\section{Recognition of Ohbayashinema spp. in mixed infections}

In all hosts, specimens of Ohbayashinema were consistently found as co-parasites with Murielus in the small intestine. Although Dikmans (1939) apparently overlooked the presence of specimens of Ohbayashinema during preparation of the original description of $M$. harpespiculus, nematodes referred to these genera are rather distinct. There may be some overlap in general dimensions for males or females for respective species in these genera. However, specimens of Ohbayashinema are always spirally coiled in contrast to any species of Murielus; the structure of the synlophe and copulatory bursa also differ considerably (Dikmans, 1939; Durette-Desset, 1974a, 1974b, 1983; Durette-Desset et al., 2000). Superficial morphological comparisons when dealing with large numbers of Murielus in some infections could pose a challenge for correct identification of miniscule and relatively cryptic specimens of Ohbayashinema. In this regard, it is unfortunate that many published surveys of Oc. princeps neglected to submit representative vouchers to substantiate the identifications which were reported (Hoberg et al., 2009). The scope of recent geographically extensive and site intensive sampling of $O c$. princeps, however, suggests that the apparent restricted distribution of Ohbayashinema is not an artefact (Galbreath, 2009). The absence of vouchers continues as a particular problem even in recent papers on the pika helminth fauna and points to the lack of uniform policies on the part of some journals (Wang et al., 2009). 


\section{Biogeography for Ohbayashinema and Trichostrongylina in pikas}

Trichostrongyline nematodes representing Molineoidea and Heligmosomoidea are characteristic, host-specific parasites of pikas across the Holarctic, extending from east-central Asia into the western Nearctic (Durette-Desset et al., 2000; Hoberg, 2005). Within these parasite taxa, biogeographic distributions for most species are partitioned between the Palearctic and Nearctic, with little indication that single species of nematodes have broad ranges in the Holarctic. Similar to species of Graphidiella and Murielus, those of Ohbayashinema are distributed among all recognized subgroups of pikas including shrub-steppe, mountain, and northern forms (Yu et al., 2000; Hoberg, 2005). Murielus was found in a member of the shrub-steppe group, Oc. cansus, for the first time during the current study where $M$. tjanschaniensis (vouchers under USNPC 98786) was found with Oh. patriciae. The helminth faunas for most species of pikas, however, remain poorly defined, and published studies document parasites from only 12 of the 30 recognized and potential host species (Hoffmann and Smith, 2005).

Trans-continental distributions for Ohbayashinema and other Trichostrongylina involving phylogenetically divergent species of Ochotona suggest a relatively deep history of association for these host-parasite assemblages in the Holarctic extending minimally over the late Tertiary and Pleistocene (Hoberg, 2005). Origins of Ohbayashinema appear related to an early event of host colonization of Ochotona (after divergence of Ochotonidae + Leporidae) by heligmosomoids from sciurid or arvicoline rodents in Eurasia as indicated by affinities to Citellinema and Heligmosoma-Heligmosomoides (Durette-Desset, 1974a); no particular affinities with parasites of Leporidae are evident. These observations are consistent with the concept of "host capture" (Chabaud, 1965) as a primary driver for diversification among many taxa of the Trichostrongylina (Durette-Desset, 1985), and processes of colonization as more general phenomena in the radiation of complex assemblages of hosts and parasites (Hoberg and Brooks, 2008). This contrasts with the deeper coevolutionary history postulated for some molineoids in Lagomorpha, and the respective origins and diversification for Murielus in Ochotonidae and Rauschia + Nematodiroides in Leporidae coinciding with divergence of these mammalian families in the Oligocene. The trichostrongyline fauna in species of Ochotona was initially assembled in Eurasia from phylogenetically disparate sources over an extended time frame since the mid-Tertiary. Subsequently, geographic expansion from Eurasia and colonization for these assemblages across Beringia and the Nearctic occurred under the influence of episodic climate change and cyclical habitat modification during the last 2 million years (Hoberg, 2005).

Morphologically distinct groups of Ohbayashinema do not appear to be consistently associated with particular subgroups of pikas. For example, the overall similarity demonstrated for $O h$. ochotoni and Oh. patriciae in having a relatively unique number of ridges at the mid-body (10) does not appear to have a coevolutionary basis. Respective hosts are members of the ecologically divergent mountain (Oh. ochotoni in Oc. macrotis) and shrub-steppe (Oh. patriciae in Oc. cansus) subgroups of Ochotona (Yu et al., 2000). Geographically, however, these species of Ochotona may be sympatric in some areas of west-central China (Smith et al., 1990). In contrast, it is probably reasonable to assume that Ohbayashinema was present in the ancestor for $O c$. princeps and populations now partitioned between the Cascade Range (Oh. nearctica) and northern Rocky Mountains (Oh. aspeira) (Galbreath et al., 2009). Although much remains to be demonstrated about the diversity for helminths in pikas, it is apparent that factors associated with the assembly and structure of parasite faunas have been complex, involving episodic processes for geographic and host colonization along with coevolutionary mechanisms (Hoberg, 2005; Galbreath, 2009).

\section{Ohbayashinema spp. in Oc. princeps}

In those assemblages that have been explored in some detail, it appears that the distribution for different trichostrongyline nematodes represents a continuum from relatively homogeneous to highly patchy, heterogeneous, and fragmented in space and time. Even when considered within a broader trichostrongyline fauna, the distribution for Ohbayashinema in Oc. princeps appears to be highly restricted. Such a limited distribution reflects the complex geographic and climatological history for pikas, which is clearly demonstrated in the intermountain region of western North America (Galbreath et al., 2009; Galbreath, Hafner, and Zamudio, 2009). Major genetic lineages of Oc. princeps are now associated with different mountain provinces (Cascade Range, Sierra Nevada, central Utah, and northern and southern Rocky Mountain) and have been on independent evolutionary trajectories across multiple glacial cycles in the late Pleistocene (Galbreath et al., 2009). Habitat and thermal preferences for Oc. princeps served to drive localized and fragmented populations for hosts and parasites during alternating interstadial-stadial cycles of the Pleistocene as pikas tracked suitable local environments up and down elevational gradients (Hafner and Sullivan, 1995; Galbreath, Hafner, and Zamudio, 2009). Populations fragmented during periods of climate warming and coalesced during cooling events, with important consequences for the distribution of genetic structure in pikas (Galbreath et al., 2009; Galbreath, Hafner, and Zamudio, 2009) and presumably their parasites. Cohesion of lineages across the montane landscape was determined by the extent of dispersal among populations during periods of contact. Parasites with high prevalence and abundance would be better able to maintain gene flow among episodically isolated populations, whereas species with lower effective population size $\left(N_{e}\right)$ may be more prone to range fragmentation and differentiation of relictual isolates. At fine spatial scales, these mechanisms would be postulated as drivers of local, relictual distributions for host-parasite assemblages.

Trichostrongylines are present in all geographic provinces except in the Sierra Nevada Range and mountains of the Great Basin (associated with the Sierra Nevada lineage of pikas), a pattern consistent with the history of diversification for $O c$. princeps (Galbreath, 2009). Pikas apparently underwent at least 2 major rounds of diversification, i.e., an early split led to lineages in the Cascades, Sierra Nevada/Great Basin region, and eastern mountains, e.g., Rocky Mountains, and a second split that subdivided the eastern distribution and populations from the northern Rocky Mountains, southern Rocky Mountains, and central Utah (Galbreath et al., 2009). Although apparently present in the common ancestor for these lineages, all trichostrongylines were excluded from the Sierra Nevada lineage. The 
only exception is $M$. harpespiculus, which is known in host populations that neighbor other major pika lineages in which this molineoid is widespread (Galbreath, 2009). The distribution of $M$. harpespiculus in these particular populations is consistent with secondary colonization of the Sierra Nevada lineage in zones of historical contact with pikas distributed to the east.

After pikas and their parasites colonized the western mountains of North America, the initial climate-driven fragmentation into 3 regional subunits led to long-term isolation for populations of Ohbayashinema in the Cascades (Oh. nearctica) and Rocky Mountains (Oh. aspeira). Later episodes of range retraction and expansion within the Rockies, and finally another round of splitting in the east, produced the pattern of 3 eastern lineages for pikas that are closely related (Galbreath et al., 2009). Complex patterns of population expansion and contraction, in concert with an apparently small $N_{e}$ for Ohbayashinema, could result in temporally and spatially restricted distributions and result in vulnerability to local extinction and missing the boat (Paterson et al., 2003). In contrast, M. harpespiculus and G. ochotonae have broader and more homogenous geographic distributions and are both substantially more abundant (presumably relatively larger $N_{e}$ ) than Ohbayashinema based on combined published surveys and collections of 394 Oc. princeps in the current study (K. E. Galbreath and E. P. Hoberg, unpubl. obs.). If Ohbayashinema was lost from parts of its host's range because of climate-driven fluctuations, localities where it currently persists may reflect areas where populations of $O c$. princeps have been relatively stable through time. Thus, the apparently relictual distribution of the genus in North America could hint at source populations from which pikas expanded following warm periods that severely restricted their occurrence.

Understanding the historical factors, particularly climatedriven fluctuations in geographic range that have structured these faunas, suggests that the current regime for global warming and habitat modification has considerable implications for the continuity of already localized assemblages of hosts and parasites. Models for projected climate change across the landscapes occupied by $O c$. princeps predict reduction or extinctions of populations at lower elevations or latitudes, leading to local extirpation and increasing fragmentation for host populations (Galbreath, Hafner, and Zamudio, 2009). Contemporary climate warming has already been implicated in local extinction of pika populations in the Great Basin (Beever et al., 2003). An assemblage of host-specific helminths (both nematodes and cestodes) in Oc. princeps is similarly vulnerable to those events which will influence patterns of diversity associated with sky islands across western North America. Species co-extinctions and reduction in diversity at all levels in alpine communities (and other environments) with concomitant perturbations to ecosystem structure are a potential consequence of accelerated climate change (e.g., Koh et al., 2004). Such may be exacerbated by the already apparently limited distributions for such parasites as Ohbayashinema in Oc. princeps.

At an intracontinental level, climate and complex patterns of expansion and isolation for pikas may also explain the absence of Ohbayashinema and other Trichostrongylina in Oc. collaris, the apparent sister of Oc. princeps in North America. Current evidence suggests that trichostrongylines occurred in the common ancestor for pikas in North America, and that occurrence of the host-parasite assemblage represents a single expansion event from
Eurasia. Northern pikas, however, are not ancestral but appear to be peripheral isolates derived from a southern population (Rausch, 1994; Galbreath, 2009). Thus, absence of trichostrongylines in collared pikas with northern distributions is consistent with (1) an extinction event following isolation and divergence for host populations that otherwise maintain a diverse helminth fauna, or (2) these parasites were absent in the founding population for Oc. collaris.

It is apparent that episodes of fluctuating climate have had a dramatic influence on patterns of host-parasite diversity in the Nearctic and more broadly in the Holarctic (Rausch, 1994; Hoberg et al., 2003; Cook et al., 2005; Hoberg, 2005; Waltari et al., 2007). It is evident that the association for pikas and trichostrongylines is a powerful model contributing to explorations of the interaction of history, climate, and episodic processes as determinants of complex distributions for hosts and parasites.

\section{ACKNOWLEDGMENTS}

We are particularly grateful to J.-F. Dejouannet (MNHN, France) for preparation of the final figures for publication. We thank P. A. Pillit and A. Abrams of the U.S. National Parasite Collection for their assistance during preliminary examinations of specimens of Ohbayashinema. Field collections of American pikas by K.E.G. were funded by grants from the National Science Foundation (DEB 0506042), American Society of Mammalogists, Sigma Xi, Andrew Mellon Foundation (Cornell), American Museum of Natural History, and Cornell Department of Ecology and Evolutionary Biology. Specimens of Oc. cansus were collected by P. Giraudoux, F. Raoul, and J. P. Quéré of the University of Franche-Comté, with the financial support from the U.S. National Institutes of Health and the Fogarty International Center (EID TW001565-05). Field collections for Oc. collaris were a contribution from the Beringian Coevolution Project (with J. A. Cook and E.P.H. centered at the University of New Mexico), an interdisciplinary program funded by the National Science Foundation (DEB 0196095 and 0415668) exploring evolution and historical biogeography of complex host-parasite systems.

\section{LITERATURE CITED}

Barrett, R. E., And D. E. Worley. 1970. Parasites of the pika (Ochotona princeps) in two counties in south-central Montana, with new host records. Proceedings of the Helminthological Society of Washington 37: 179-181.

Beever, E. A., P. F. Brussard, and J. Berger. 2003. Patterns of extirpation among isolated populations of pikas (Ochotona princeps) in the Great Basin. Journal of Mammalogy 84: 37-54.

Chabaud, A. G. 1965. Spécificité parasitaire. I. Chez les Nématodes parasites de Vertébrés. In Traité de zoologie, vol. 4, P. P. Grassé (ed.) Masson, Paris, France, p. 548-557.

Cook, J. A., E. P. Hoberg, A. Koehler, H. Henttonen, L. Wickström, V. Haukisalmi, K. Galbreath, F. Chernyavski, N. Dokuchaev, A LAHZUHTKIN ET AL. 2005. Beringia: Intercontinental exchange and diversification of high latitude mammals and their parasites during the Pliocene and Quaternary. Mammal Study 30: S33-S44.

Dikmans, G. 1939. Two new nematodes (Trichostrongyloidea) from rodents. Proceedings of the Helminthological Society of Washington 6: $1-4$.

Durette-Desset, M.-C. 1974a. Obayashinema ochotoni n. gen, n. sp. (Nematoda: Trichostrongyloidea), parasite d'un lagomorphe du Népal: Intérêt phylétique de ce genre. Bulletin Museum national Histoire naturelle, Paris 144: 415-418.

- 1974b. Murielus abei (Nematoda Heligmosomidae), parasite d'un lagomorphe du Népal, et remarques sur le genre Murielus Dikmans, 1939. Bulletin Museum national Histoire naturelle, Paris 144: 419424

. 1983. Keys to genera of the superfamily Trichostrongyloidea, No. 10. In CIH keys to the nematode parasites of vertebrates, R. C. Anderson and A. G. Chabaud (eds.). Commonwealth Agricultural Bureaux, Farnham Royal, U.K., p. 1-86. 
. 1985. Trichostrongyloid nematodes and their vertebrate hosts: Reconstruction of the phylogeny of a parasitic group. Advances in Parasitology 24: 239-306.

, AND A. G. Chabaud. 1981. Nouvel essai de classification des Nématodes Trichostrongyloidea. Annales de Parasitologie Humaine et Comparée 56: 297-312.

- AND - 1993. Nomenclature des Strongylida au-dessus du groupe famille. Annales de Parasitologie Humaine et Comparée 68: 111-112.

, S. Ganzorig, F. Audebert, and M. Kamiya. 2000. A new species of the genus Ohbayashinema (Nematoda, Trichostrongylina, Heligmosomoidea), parasite of Ochotona daurica (Ochotonidae, Lagomorpha) from Buriatia. ZooSystema 22: 667-676.

Galbreath, K. E. 2009. Of pikas and parasites: Historical biogeography of an alpine host-parasite assemblage. Ph.D. Dissertation. Cornell University, Ithaca, New York, $183 \mathrm{p}$.

- D. J. Hafner, And K. R. Zamudio. 2009. When cold is better: Climate driven elevation shifts yield complex patterns of diversification and demography in an alpine specialist (American pika, Ochotona princeps). Evolution 63: 2848-2863.

,$\frac{-}{-}$, AND K. Agnew. 2009. Isolation and introgression in the Intermountain West: Contrasting gene genealogies reveal the complex biogeographic history of the American pika (Ochotona princeps). Journal of Biogeography 37: 344-362.

Giraudoux, P., D. Pleydell, F. Raoul, J.-P. Quéré, Q. Wang, Y. Yang, D. A. Vutton, J. Qiu, W. YANG, And P. S. CRaig. 2006. Transmission ecology of Echinococcus multilocularis: What are the ranges of parasite stability among various host communities in China? Parasitology International 55: S37-S46.

Grundmann, A. W., And P. S. Lombardi. 1976. Parasitism of the pika, Ochotona princeps Richardson (Mammalia: Lagomorpha), in Utah and Nevada with the description of Eugenuris utahensis sp. n. (Nematoda: Oxyuridae). Proceedings of the Helminthological Society of Washington 43: 39-46.

Gvozdev, E. V. 1962. Analiz gel'mintofauny pishchukh (Ochotonidae) sviazi s geograficheskim rasprostran eniem khoziaev. Parazity Dikikh Zhivotnykh Khazakstana. Trudy Instituta Zoologi Academia Nauk Kazakhstan SSR 16: 63-80.

, V. L. Kontrimavichus, K. M. Rhyzhikov, and L. S. Shaldybin. 1970. Opredelitel' gel'mintov zaitseobraznykh SSSR. Izdatel'stvo Nauka, Moskow, USSR, 232 p.

Hafner, D. J., And R. M. Sullivan. 1995. Historical and ecological biogeography of Nearctic pikas (Lagomorpha: Ochotonidae). Journal of Mammalogy 76: 302-321.

Новвs, R. P. 1980. Interspecific interactions among gastrointestinal helminths in pikas of North America. American Midland Naturalist 103: $15-25$.

Hoberg, E. P. 2005. Coevolution and biogeography among Nematodirinae (Nematoda: Trichostrongylina) Lagomorpha and Artiodactyla (Mammalia): Exploring determinants of history and structure for the northern fauna across the Holarctic. Journal of Parasitology 91: 358-369.
, AND D. R. BRooks. 2008. A macroevolutionary mosaic: Episodic host-switching, geographical colonization and diversification in complex host-parasite systems. Journal of Biogeography 35: 15331550 .

, S. J. Kutz, K. Galbreath, and J. Cook. 2003. Arctic biodiversity: From discovery to faunal baselines-Revealing the history of a dynamic ecosystem. Journal of Parasitology 89(Suppl.): S84-S95.

, P. A. Pilitt, and K. E. Galbreath. 2009. Why museums matter: A tale of pinworms (Oxyuroidea: Heteroxynematidae) among pikas (Ochotona princeps and O. collaris) in the American West. Journal of Parasitology 95: 490-501.

Hoffmann, R. S., And A. T. Smith. 2005. Order Lagomorpha, Family Ochotonidae. In Mammal species of the world, a taxonomic and geographic reference, 3rd ed., vol. 1, D. E. Wilson and D. M. Reeder (eds.). Johns Hopkins University Press, Baltimore, Maryland, p. 185194.

Koh, L. P., R. R. Dunn, N. S. Sodhi, R. K. Colwell, H. C. Proctor, And V. S. Smith. 2004. Species coextinctions and the biodiversity crisis. Science 305: 1632-1634.

Olsen, L. S. 1948. A new trichostrongylid nematode from the pika, Ochotona princeps figginsi. American Midland Naturalist 39: 748753.

Paterson, A. M., R. L. Palma, and R. D. Gray. 2003. Drowning on arrival, missing the boat and $\mathrm{X}$ events: How likely are sorting events? In Tangled trees: Phylogeny, cospeciation and coevolution, R. D. M. Page (ed.). University of Chicago Press, Chicago, Illinois, p. 287-309.

Rausch, R. L. 1994. Transberingian dispersal of cestodes in mammals. International Journal for Parasitology 24: 1203-1212.

SeEsee, F. M. 1973. The helminth parasites of the pika, Ochotona princeps princeps (Richardson, 1828), in northern Idaho. American Midland Naturalist 89: 257-265.

Smith, A. T., N. A. Formozov, R. S. Hoffmann, Z. Changlin, and M. A. Erbajeva. 1990. The pikas. In Rabbits, hares and pikas: Status, survey and conservation action plan, J. A. Chapman and J. E. C. Flux (eds.). IUCN, SSC Lagomorph Specialist Group. IUCN, Gland, Switzerland, p. 14-60.

Tinnin, D. S., S. L. Gardner, and S. Ganzorig. 2008. Helminths of small mammals (Chiroptera, Insectivora, Lagomorpha) from Mongolia with a description of a new species of Schizorchis (Cestoda: Anoplocephalidae). Comparative Parasitology 75: 107-114.

Waltari, E., E. P. Hoberg, E. P. Lessa, And J. A. Cook. 2007. Eastward ho: Phylogeogrpahical perspectives on colonization of hosts and parasites across the Beringian nexus. Journal of Biogeography 34: $561-574$.

Wang, C., H. He, M. Li, F. Lei, J. Root, Y. Wu, and J. Qin. 2009. Parasite species associated with wild plateau pika (Ochotona curzoniae) in southeastern Qinghai Province, China. Journal of Wildlife Diseases 45: 288-294.

Yu, N., C. Zheng, Y.-P. ZHeng, AND W.-H. Li. 2000. Molecular systematics of pikas (genus Ochotona) inferred from mitochondrial DNA sequences. Molecular Phylogenetics and Evolution 16: 85-95. 